\title{
角柱粗度を有する開水路流れの抵抗特性および流れ場 に与える高濃度土砂の影響 \\ EFFECTS OF HYPERCONCENTRATED SEDIMENT ON FLOW RESISTANCE AND FLOW STRUCTURE IN AN OPEN CHANNEL WITH REGULALY ARRAYED SQUARE RIBS
}

\author{
大本照憲 ${ }^{1} \cdot$ Liany Hendratta ${ }^{2} \cdot$ 西将吾 $^{3}$ \\ Terunori OHMOTO, Liany Hendratta and Shogo NISHI
}

1 正会員 工博 熊本大学教授 大学院自然科学研究科社会環境工学専攻（† $860-8555$ 熊本市黒髪 2 丁目 $39-1)$

2 学生会員 熊本大学大学院自然科学研究科博士後期課程 （同上）
3学生会員 熊本大学大学院自然科学研究科博士前期課程 （同上）

\begin{abstract}
The necessity to understand and predict flows that carry large suspended sediment and wash loads has become acute in the Shirakawa River Basin where significant erosion and siltation associated with hyperconcentrated flood give rise to many river problems. Mud flows, debris flows or slurries, made up of a large amount of clay and/or silt particles suspended in water, often show non-Newtonian properties but remain poorly understood concerning the impacts of their rheological properties on fully developed turbulent structure.

In this paper, we experimentally investigated resistance and momentum transport of hyper- concentrated sediment laden-flow in an open channel with two-dimensional square ribs by using Particle Image Velocimetry(PIV). The results showed that rheological properties significantly dissipated the turbulent flow fluctuations over the dune bed and augmented the flow resistance by comparison with the clear water flow.
\end{abstract}

Key Words : non-Newtonian fluids, open channel flow, two-dimensional square ribs, PIV

\section{1. はじめに}

微細土砂を大量に含有する高濃度土砂流は泥流や黄河 流域の河川，有明海湾奥部の六角川河口域において潟土 を含さ潮流など様々な条件下において観察されている. また、熊本県の白川では昭和28年6月26日水害において 土砂の体積濃度は10\%を示したことが報告されている。

土砂濃度の高い流れの動力学特性は, 清水流とは大き く異なり, 粘性や密度が増大すると同時に, 乱れの強さ, 土砂の濃度分布，流れの抵抗特性および土砂輸送能力が 変質することが予想されるが，その流動機構については 不明な点が多い.

高濃度土砂流の定義は研究者により異なる. Bradley \&McCutcheon(1985）11)は，体積濃度が20\%以下では密度 や粘性への影響が小さい標準的な水流とし，20\%以上で その特徴が現れ，特に，粘土やシルトの体積濃度が5\% 以上の土砂流では非ニュートン流体特性を示すことが指 摘されている．土砂濃度以外に粒子の大きさ，形状，粒 度分布, 土粒子中のミネラル含有量も, 高濃度流を特徴 付けるパラメータとなる. ミネラルを多く含んだ土砂が 流れ込む黄河においては，濃度 $200 \mathrm{~kg} / \mathrm{m}^{3}$, 体積濃度が約 8\%以上を高濃度と定義されている22.
銭寧 ${ }^{3)} ら$ はビンガム流体モデルを，P. Coussot ${ }^{4)}$ は降伏 応力を持つ擬塑性流体モデルを用いて降伏応力や粘性係 数が粒子濃度や粒度分布との関数関係を求めた. 芦田 ${ }^{5)}$ らはビンガム流体モデルを対象にとして電気 2 重層の概 念を用いて粒子同士の結合力を評価し，せん断に伴う結 合の切断エネルギーに基づいて降伏応力や粘性係数の表 示式を導いた. 江頭(6)らは従来の土石流の研究の元に非 粘着性土砂流を研究対象とし, 土砂濃度によるカルマン 係数の変化に着目し構成方程式を導いていた. しかし, これらの研究は非ニュートン流体流れの構造や抵抗則に ついては明らかにしていない，一方，添加剤を含む管路 流れでは， $\mathrm{Toms}^{7}{ }^{7}$ による直鎖状高分子剤をわずかに含む 溶液の管路実験では，溶媒のみの場合に比べて著しい抵 抗低減が見出され，トムズ効果として広く知られている. 機械系分野では直鎖状高分子剂だけでなく，界面活性剂， パルプ繊維，微細気泡にも類似の効果があることが明ら かにされ，界面活性剤と高分子剤を用いた宗像 による 管路実験では最大 $70 \%$ の抵抗低減が観測されている.

近年,土石流との関連で高濃度土砂流の基本特性が Pierson(2005) ${ }^{9)}$ によってレビューされ、その中でも抵抗 特性および乱流構造について不明な点が指摘されている.

著者等 ${ }^{10,11)}$ は，高濃度土砂流における非二ュートン流 体特性に着目し，黄河下流域の済南市で採取した河床材 
料と市販の粘土（カオリン）を用いて高濃度土砂流を管 路流、開水路流に発生させ，その抵抗特性を検討した。

黄河土砂とカオリンの何れも土砂濃度の増大に伴って 摩擦損失係数は増大し，体積濃度が $10 \%$ で清水に比べて 黄河土砂で1.30倍, カオリンで1.28倍であり, 黄河土砂 の方が若干大きな值を示した。 また, 高濃度土砂流にお いては粘性係数のせん断速度依存性が強く現れ，低せん 断速度においては高濃度土砂流の粘性係数は清水に較心゙ て $10^{2} \sim 10^{3}$ 倍にまで達すること，および粘性係数のせん 断速度依存性がビンガム流体モデルでは説明できないこ とが認められ，低せん断速度領域においてPower-lawモ デルにより近似できることを明らかにした．また，高濃 度土砂流と類似な粘性特性を持つ高分子剂を用いた滑面 開水路流れにおける乱流計測により強い粘性により乱れ が抑えられ層流化されることが明らかになった。

本研究では, 形状抵抗に着目し二次元角柱粗度を有す る開水路流れにおいて高濃度土砂が流れの抵抗およびそ の流動機構に与える影響を検討した。なお流動機構につ いてはカオリンを用いた高濃度土砂流と類似の粘性特性 を有するポリアクリル酸ソーダ (PSA) 溶液を用い，流 速の計測に PIV(Particle Image Velocimetry) を適用し て, 流れ場を清水流との比較を通して詳細に検討した.

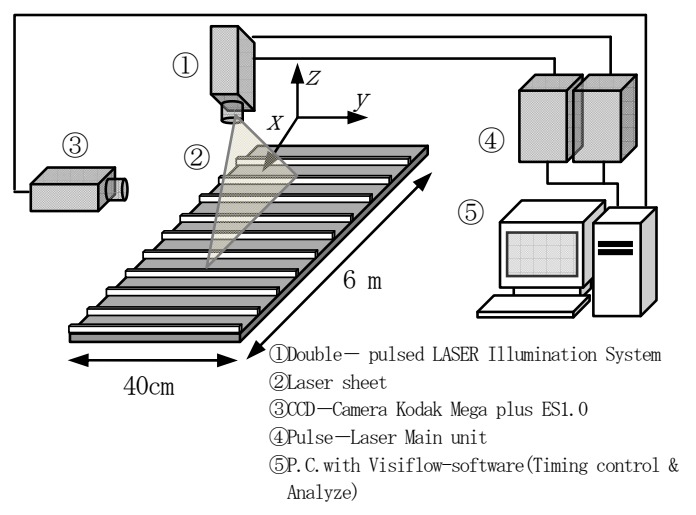

図-1 流れの計測システム

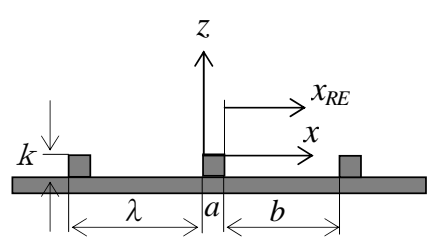

図-2 水路床境界条件

\section{2. 実験装置および実験方法}

実験に使用した水路は，長さ $10 \mathrm{~m}$, 幅 $40 \mathrm{~cm}$, 高さ $20 \mathrm{~cm}$ の 可変勾配型の循環式直線水路である. 水路床および側壁 はアクリル樹脂製となっており，側壁からのカメラ撮影， レーザー光が照射可能となっている.

右手座標系を用い，流下方向を $x$ 軸，水路横断方向を

\section{表-1＼cjkstart流れの抵抗に関する実験条件}

\begin{tabular}{|c|c|c|c|c|}
\hline \multicolumn{2}{|c|}{ Case } & $\begin{array}{c}\text { Concen- } \\
\text { tration }\end{array}$ & $\begin{array}{c}\text { Discharge } \\
(\mathrm{l} / \mathrm{s})\end{array}$ & $\begin{array}{c}\text { Channel } \\
\text { slope (Io) }\end{array}$ \\
\cline { 1 - 2 } $\begin{array}{c}\text { Kaolin } \\
\text { Suspension }\end{array}$ & $k=5 \mathrm{~mm}$ & $\begin{array}{c}C v=0 \sim \\
12 \%\end{array}$ & \multirow{2}{*}{4} & $1 / 500$ \\
\cline { 2 - 3 } & $k=10 \mathrm{~mm}$ & & \\
\hline $\begin{array}{c}\text { PSA } \\
\text { Solution }\end{array}$ & $k=5 \mathrm{~mm}$ & $\begin{array}{c}C w=0 \sim \\
800 \mathrm{mg} /\end{array}$ & & \\
\cline { 2 - 2 } & $k=10 \mathrm{~mm}$ & & & \\
\hline
\end{tabular}

表-2 流速計測の実験条件

\begin{tabular}{|c|c|c|c|c|}
\hline & & Case 1 & Case 2 & Case 3 \\
\hline PSA concentration & $C w(\mathrm{mg} / \mathrm{l})$ & 0 & 300 & 800 \\
\hline Discharge & $Q(/ / s)$ & 4.0 & 4.0 & 4.0 \\
\hline Flow depth & $H(\mathrm{~cm})$ & 7.96 & 7.19 & 9.61 \\
\hline Roughnesshigh & $k(\mathrm{~mm})$ & 10 & 10 & 10 \\
\hline Mean flow velocity & $U_{m}(\mathrm{~cm} / \mathrm{s})$ & 12.56 & 13.91 & 10.41 \\
\hline Friction flow velocity & $U_{*}(\mathrm{~cm} / \mathrm{s})$ & 3.95 & 3.75 & 4.34 \\
\hline Maximum flow velocity & $\mathrm{y} U_{0}(\mathrm{~cm} / \mathrm{s})$ & 16.24 & 19.45 & 19.18 \\
\hline Channel slope & $I_{0}$ & $1 / 500$ & $1 / 500$ & $1 / 500$ \\
\hline Froudenumber & $U m /(g H)^{1 / 2}$ & 0.14 & 0.17 & 0.11 \\
\hline Reynolds number & $U m H / v$ & 10,000 & - & - \\
\hline
\end{tabular}

$y$ 軸，鉛直上向きを $z$ 軸とし，それぞれに対応した平 均流速成分 $U, V, W$ と寸る.

座標系の詳細は図一1，粗度の縦断配列を図一2に示寸。 図中の $X_{R E}$ は, 粗度後縁からの流下距離を示寸. 粗度材料 は，ステンレス製から成る一辺 $k=a=10 \mathrm{~mm} の$ 正方形断面 および $k=5 \mathrm{~mm}, a=10 \mathrm{~mm}$ の長方形断面の角柱粗度を使用し た. 水路床は, 水路上流端より $2 \mathrm{~m}$ の位置から流下方向 に6mの長さに亘って配置した.

土砂濃度が流れの抵抗に与える影響を検討した実験条 件を表一1に示寸，本実験では、カオリンを用いた体積 土砂濃度 $\left(C_{v}=0-12 \%\right)$ およびポリアクリル酸ソーダ

(PSA) 溶液の濃度 $\left(C_{W}=0-800 \mathrm{mg} / \ell\right)$ を変え、縦断方向 の粗度間隔 $\lambda$ は $k=5 \mathrm{~mm}$ では $\lambda / k=8, \quad k=10 \mathrm{~mm}, て ゙ は \lambda / k=10$ に設定した．上記 $\lambda / k$ の值は、著者等 ${ }^{11)}$ の実験によれば 清水流における二次元角柱粗度の縦断間隔 $\lambda$ の変化に対 して抵抗係数が最大值を示したためである.

流れは所定の流量を通水し下流端の堰を調節すること により等流場を形成し，ポイントゲージを用いて等流水 深を計測した。 なお，粗度配置区間は6mで，その上流端 および下流端近傍では不等流となるが中央部の $3 \mathrm{~m} \sim 4 \mathrm{~m} の$ 区間では水深はほぼ一様であり等流場と判断出来た.

土砂濃度が流動機構に与える影響を検討した実験条件 を表一2に示寸. 後述する様に高濃度土砂流を模擬した ポリアクリル酸ソーダ (PSA) 溶液の濃度 $C_{W}=300 \mathrm{mg} / \ell$ および800 mg/l は、ほぼ同一の抵抗係数および粘性係 数から試算すればそれぞれ、カオリンの体積土砂濃度 


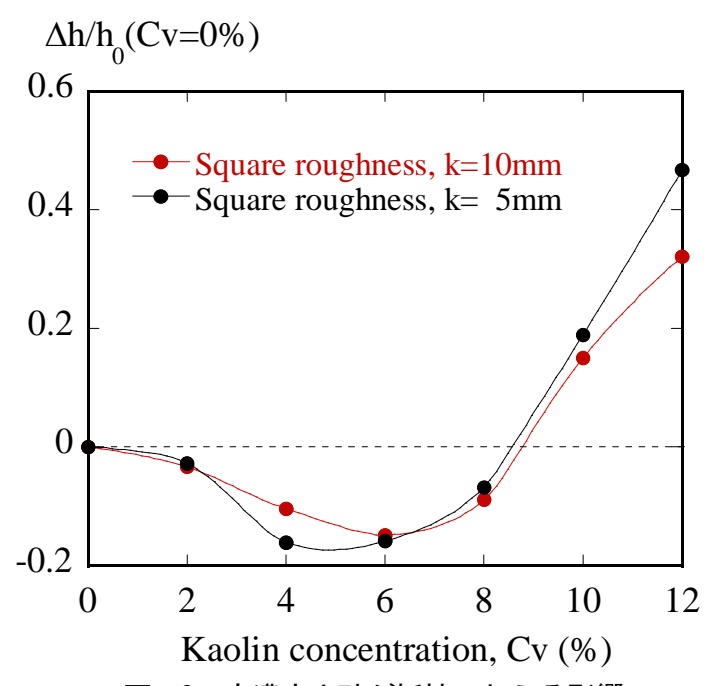

図-3 高濃度土砂が抵抗に与える影響

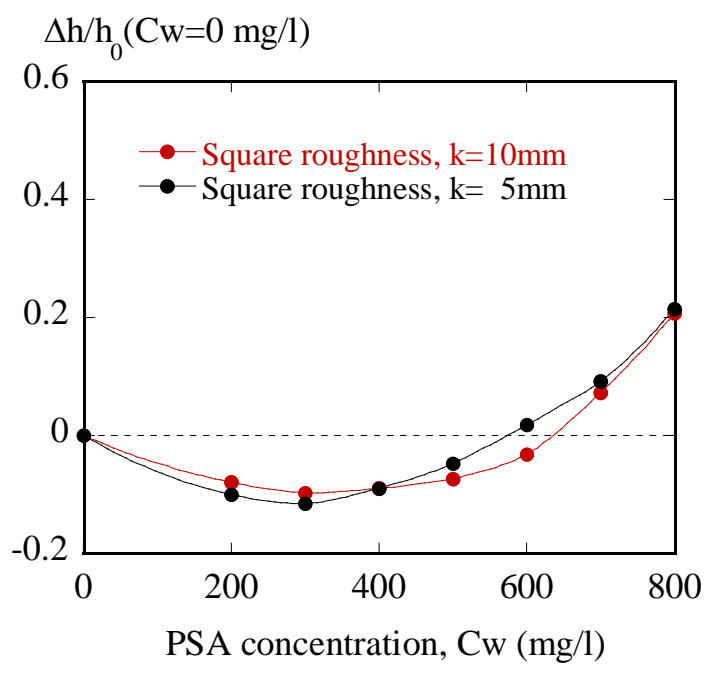

図一4 PSA濃度が抵抗に与える影響

$C_{V}=6 \%$ および10\%に相当する．なお、ポリアクリル酸ソー ダ（PSA）溶液は、粘性特性においては高濃度土砂流を 良好に再現することおよび無色透明であることから流れ の計測にPIV計測が可能であるという利点を有する。

流速の計測には，非接触型の代表的な画像処理法であ るPIV (Particle-Image Velocimetry) 法を用いた。計測 システムの概要を図ー1に示す．測定位置は，粗面先端 より $4 \mathrm{~m}$ 下流位置の等流場で行った．光源には空冷式の赤 外線パルスレーザーを用い，シート光の厚さを $1 \mathrm{~mm} ， ハ 0$ ルス間隔を $1000 \mu \mathrm{s}$ に設定し，水路上方から底面に垂直 下向きに照射した.

レーザー光とCCDカメラを同期させて読み込まれた可 視化画像は, 100fps (frame per second), $960 \times 1018$ (pixe1)のモノクロビデオ画像としてコンピューターの ハードディスクに記録され，PIV法により画像処理され た.レンズは焦点距離が50mmのものを用い, 1 pixe1の最 小サイズは0.06mmである.流速のサンプリング周波数は $100 \mathrm{~Hz}$ ，1計測面での画像データは2000枚，計測時間は 20secであった. なお，トレーサーとして粒径 $30 \mu \mathrm{m}$ ，比 重1.02のナイロン粒子をアルコール液で十分に攪拌して
PSA concentration, Cw (mg/l)

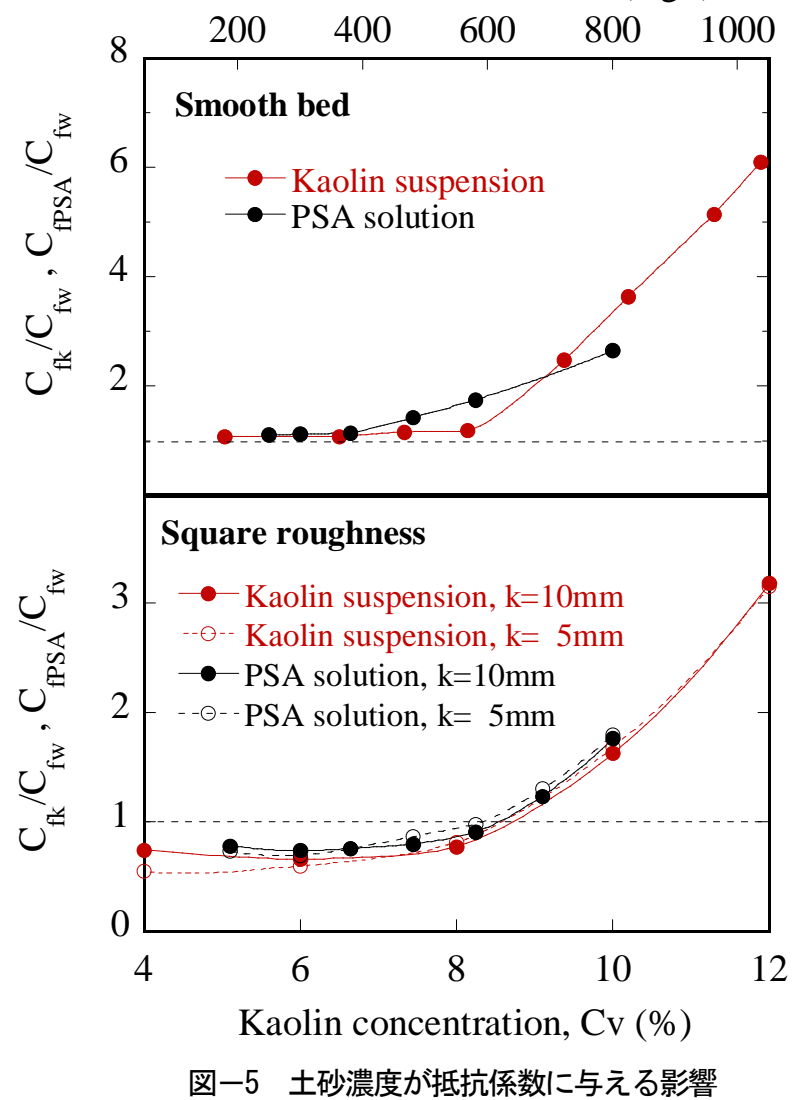

水中に注入した.

\section{3. 土砂濃度が抵抗特性に与える影響}

滑面開水路の浮遊砂流においては，高濃度土砂流の抵 抗は，中央粒径 $d_{50}$ が $0.026 \mathrm{~mm}$ のシルトを用いた実験では 土砂濃度の増大に伴って抵抗が減少傾向を示寸場合 ${ }^{12)}$ 逆に粘土を用いたWang (1993) ${ }^{13)}$ の実験では体積濃度が 約 $9 \%$ で若干増大することが報告され，現在の所，粘土 やシルトを高濃度に含む土砂流に関しては，体系的な実 測データは得られておらず, 濃度の増大に伴う抵抗の増 減についての統一的見解は得られていない.

図一3および4は，それぞれ，二次元角柱粗度における 土砂濃度 $C_{r}$ およびポリアクリル酸ソーダ $(\mathrm{PSA})$ 溶液の

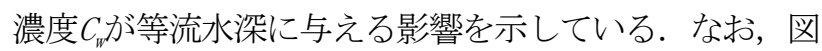
の縦軸は土砂流およびPSA溶液の等流水深と清水流の等 流水深との差を清水流の等流水深によって無次元化した 次式で与えた.

$$
\begin{aligned}
& \Delta h / h_{0}\left(C_{i}=0\right) \\
&=\left\{h_{0}\left(C_{i}\right)-h_{0}\left(C_{i}=0\right)\right\} / h_{0}\left(C_{i}=0\right) . \\
& \text { ここに、土砂流においては } C_{i}=C_{V} 、 P S A \text { 溶液の流れにお } \\
& \text { いては } C_{i}=C_{W} \text { である. }
\end{aligned}
$$

図ー3より粗度高さ $k=5 \mathrm{~mm} \quad(\lambda / k=8)$ および $k=10 \mathrm{~mm}$ $(\lambda / k=10)$ の何れにおいても土砂流は清水流に較べて 
体積土砂濃度が $C_{V}<8.5 \%$ では等流水深が小さく抵抗の 小さいこと、逆に $C_{V}>8.5 \%$ では等流水深が大きく抵抗の 大きいことが認められる. 特に, 粗度高さ $k=5 \mathrm{~mm}$ では $C_{V}=4-6 \%$ で極小值を示し $\Delta h / h_{0}\left(C_{V}=0\right)=-0.16$, $k=10 \mathrm{~mm}$ では $C_{V}=6 \%$ で極小值を示し $\Delta h / h_{0}\left(C_{V}=0\right)=$ -0.15であり有意な差が現れている. 一方, 体積土砂濃 度 $C_{V}>8.5 \%$ の $C_{V}=10 \%$ においては $k=5 \mathrm{~mm} て ゙$ $\Delta h / h_{0}\left(C_{V}=0\right)=0.19, k=10 \mathrm{~mm}$ で $\Delta h / h_{0}\left(C_{V}=0\right)=0.15$ で あることから水深の増加が著しい．

熊本県の白川では昭和28年6月26日水害において新規 火山灰（ヨナ）の体積濃度が10\%であったために河道計 画では水量に加えて土砂量 $10 \%$ を加えた $3400 \mathrm{~m}^{3} / \mathrm{s}$ を基本 高水に設定している．阿蘇火山灰が大量に混入した高濃 度土砂流においては単に流量が増加するだけでは無く, 抵抗が大幅に増大することに留意する必要がある.

図ー4より粗度高さ $k=5 \mathrm{~mm}(\lambda / k=8)$ および $k$ $=10 \mathrm{~mm}(\lambda / k=10)$ の何れにおいてもPSA溶液の濃度 $C_{W}$ が等流水深に与える影響は, カオリンを用いた土砂濃度 $C_{V}$ の影響に類似した傾向を示している. 具体的には土砂 PSA溶液の流れは清水流に較べて $C_{W}<600 \mathrm{mg} / \ell$ では等流 水深が小さく, $C_{W}>600 \mathrm{mg} / \ell$ では逆に等流水深が大き くなる傾向を示す. なお、PSA溶液の濃度 $C_{W}=600 \mathrm{mg} / \ell$ は, カオリンの土砂濃度 $C_{V}=8.5 \%$ に相当する. 粗度高 さ $k=5 \mathrm{~mm}$ おび $10 \mathrm{~mm}$ においてPSA溶液の濃度 $C_{W}=300$ $m g / \ell$ で極小值を示し,$k=5 \mathrm{~mm}$ では $\Delta h / h_{0}\left(C_{W}=0\right)=-0.10$, $k=10 \mathrm{~mm}$ では $\Delta h / h_{0}\left(C_{W}=0\right)=-0.11$ でありカオリン士砂流 と類似している. PSA溶液の濃度 $C_{W}=300 \mathrm{mg} / \ell$ は, カ才 リンの土砂濃度 $C_{V}=6 \%$ に相当する.

図一5にカオリン懸濁液及びPSA水溶液を用いた開水路 実験の全抵抗係数と濃度との関係を示す. 全抵抗係数は, 流体の慣性力に対する全抵抗の比として定義され式(2)で 表される.

$$
C_{f}=2\left(U_{*} / U_{m}\right)^{2}
$$

ここに， $U_{*}=\sqrt{g h i_{0}}, g$ は重力加速度， $i_{0}$ は水路勾配， Um は断面平均流速である. 図中の縦軸は清水の全抵抗 係数 $C_{f W}$ に対するカオリン懸濁液の全抵抗係数 $C_{f K}$ の割 合 $C_{f K} / C_{f W}$ およびPSA水溶液の全抵抗係数 $C_{f P S A} / C_{f W}$ を 示す。なお、困中には滑面開水路におけるデータも補足 している.

抵抗係数 $C_{f K} / C_{f W}$ はカオリン愳濁液 $C_{V}=2 \sim 8 \%$ 範囲 では、粗度高さ $k=5 \mathrm{~mm}$ では0.54-0.98 0 範囲, $k=10 \mathrm{~mm}$ では 0.65-0.91の範囲で変化し，土砂流は清水流に較べて抵抗 の小さくなることが分かる．特に， $k=5 \mathrm{~mm} て ゙ は ， C_{V}=4 \%$ で極小值を示し $C_{f K} / C_{f W}=0.54 、 k=10 \mathrm{~mm}$ では， $C_{V}=6 \%$ で極小值を示し $C_{f K} / C_{f W}=0.66$ であ. 一方, PSA溶液 の全抵抗係数 $C_{f P S A} / C_{f W}$ は, PSA溶液の濃度 $C_{W}=200 \sim 600$ $m g / \ell$ の範囲では、粗度高さ $k=5 \mathrm{~mm}$ では0.72-1.0の範囲、 $k=10 \mathrm{~mm}$ では0.74-0.91の範囲で変化し，抵抗低減は土砂流 の方が大きいが傾向は類似している.

なお、滑面開水路におけるカオリンの土砂流では，抵 抗係数 $C_{f K} / C_{f W}$ は、 $C_{V}<8 \%$ ではほぼ1に近く、清水流と 大差は無く, $C_{V}>8 \%$ では土砂濃度に比例して増大する傾 向がある. $C_{V}<8 \%$ では二次元角柱粗度において微細土砂 は，形状抵抗を大幅に削減することが認められた。この 原因として, 滑面河床では微細土砂はレイノルズ応力の 減少に伴う摩擦抵抗の減少と粘性抵抗の増大が相殺され, 一方、角柱粗度では形状抵抗の減少が挙げられる。

体積土砂濃度 $C_{V}>8.5 \%$ の $C_{V}=10 \%$ において抵抗係数 $C_{f K} / C_{f W}$ は、 $k=5 \mathrm{~mm}$ で1.68, $k=10 \mathrm{~mm}$ で1.63であり, 滑面開水路では3.63であり土砂濃度の増大に伴う抵抗係 数の増大が著しい. 体積土砂濃度 $C_{V}=10 \%$ に相当する $C_{W}=800 \mathrm{mg} / \ell$ のPSA溶液の全抵抗係数 $C_{f P S A} / C_{f W}$ は, $k$ $=5 \mathrm{~mm}$ で1.79, $k=10 \mathrm{~mm}$ で1.76であり，滑面開水路では 2.65に達することから, 土砂流に較べて二次元角柱粗度 では類似の值であるが，滑面においては小さな值となる。 水路測岸の粗度キャビティーの目視観察から二次元角 柱粗度ではカオリンを用いた土砂流では粗度背後に若干 カオリンの堆積が見られ，このことがPSA溶液に較べて 抵抗係数が若干小さくなった原因と推察される. 一方、 滑面開水路では底面近傍の目視観察は不可能ではあった. なお，Wang等 (1998) ${ }^{14)}$ の実験的研究では, 粘土を用い た磒床上の高濃度土砂流において土砂濃度の増大に伴い 抵抗が小さくなることを指摘した. さらに, 粘土粒子の 三次元的フロック形成が乱れの発生を抑制し抵抗低減の 支配因子であり, 粘性係数の増大は副次的であると結論 づけた。しかし, 礫床上の凹らを粘土粒子が覆い粗面境 界が滑面境界に変質した可能性があることには触れてい ない.

\section{4. 時間平均流の特性}

本節では， $k=10 \mathrm{~mm}(\lambda / k=10)$ を用いた表-2の実験 条件で得られた流れの計測結果から, 高濃度土砂流にお ける土砂が流れに与える影響について考察する。 なお， 高濃度土砂流では流速の計測が極めて困難であることか ら，模擬流体として粘性特性が高濃度土砂流に類似する PSA溶液を用いた。

図一6は，清水流，PSA溶液の濃度 $C_{W}=300 \mathrm{mg} / \ell （$ カ リン土砂濃度 $C_{V}=6 \%$ に相当）および $C_{W}=800 \mathrm{mg} / \ell$ （カ オリン土砂濃度 $C_{V}=10 \%$ に相当）における時間平均流の 主流速成分のカラー・コンターを示寸。なお、図中の実 線は以下の式(3)で定義される流れ関数等值線を示す.

$$
\psi(x, z)=\int_{0}^{z} U_{m}(x, \zeta) d \zeta
$$



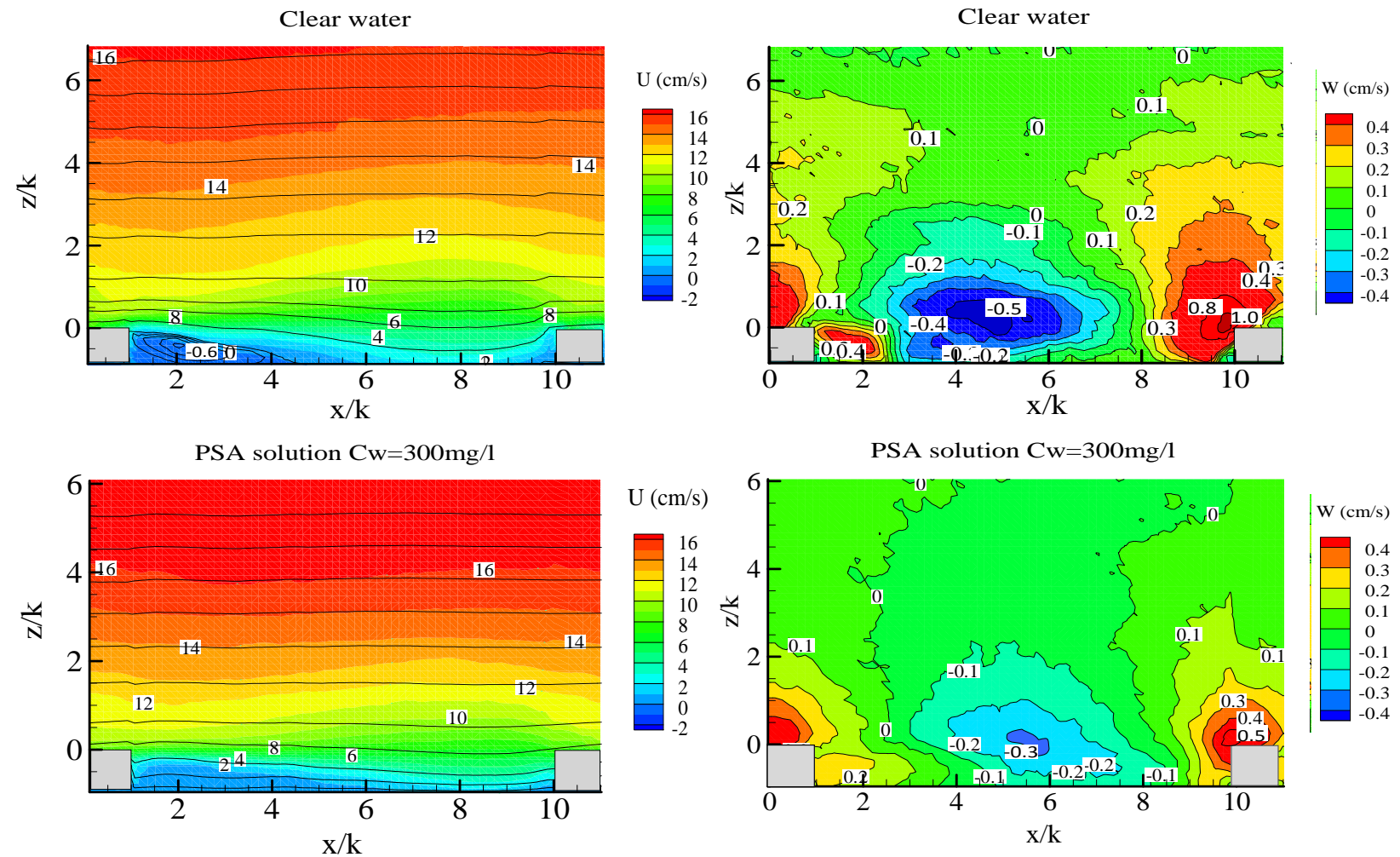

PSA solution $\mathrm{Cw}=800 \mathrm{mg} / \mathrm{l}$
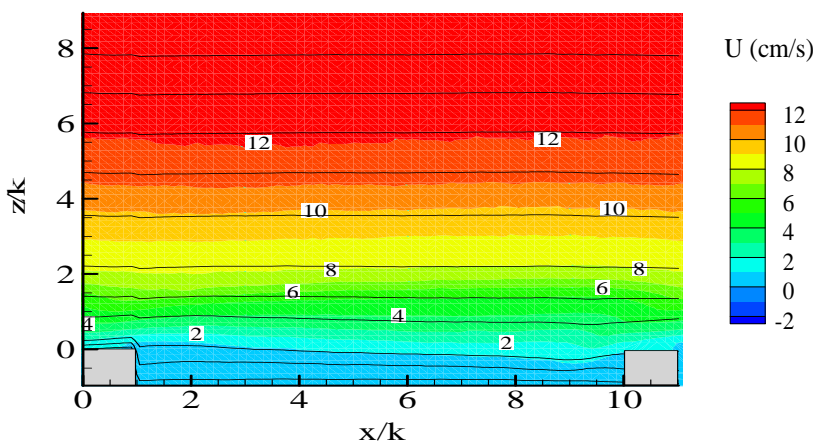

図一～主流速

図より, 清水流では粗度頂部から剥離した流線は, $x / k=4.5$ において粗度キャビティーの河床面に再付着して いること, 剥離線より下層では, 循環流が形成されるこ とが認められる. 再付着点位置は一般的な砂堆の位置に 近い. また, 主流速の等值線は, 粗度キャビティー内で は下に凸，粗度上層では上に凸の形状である。一方， $\mathrm{PSA}$ 溶液の濃度 $C_{W}=300 \mathrm{mg} / \ell$ および $C_{W}=800 \mathrm{mg} / \ell$ では, 流線の剥離は認められず，粗度キャビティー内において も清水流に較心流線は河床面に平行に近い.

主流速の等值線は, PSA溶液の濃度 $C_{W}=300 \mathrm{mg} / \ell$ では 清水流と $C_{W}=800 \mathrm{mg} / \ell$ の中間のパターンを示し, $C_{W}=800 \mathrm{mg} / \ell$ では清水流とは異なり流下方向に大きな変 化は無く, $C_{W}=300 \mathrm{mg} / \ell$ および $C_{W}=800 \mathrm{mg} / \ell$ では水面近 傍で主流速は鉛直方向に変化は小さくplug flowに近い 傾向を形成し, その傾向は $C_{W}=800 \mathrm{mg} / \ell$ でさらに強くな ることが分かる.非ニュートン流体の特性を示寸高濃度 の土砂 ${ }^{11} 1$ は, 粘性抵抗の増大に加えて流線の剥離を抑制 し, 粗度近傍の運動量輸送を減少させる効果がある.

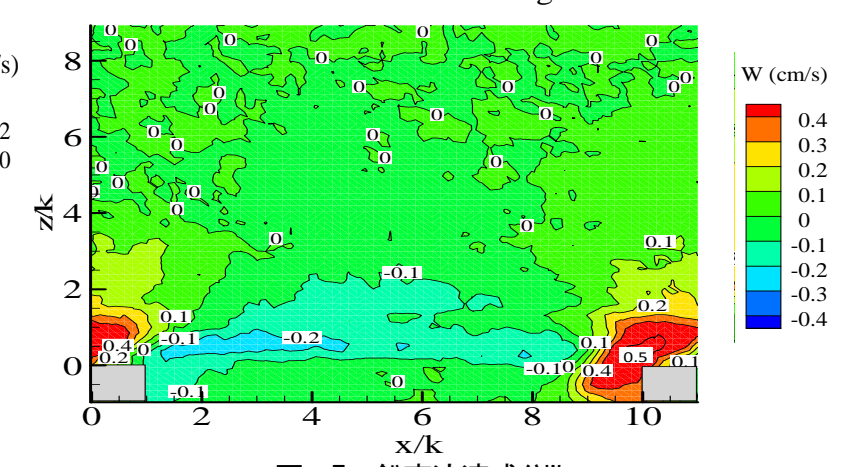

図-7 鉛直流速成分W

図一7は，清水流，PSA溶液の濃度 $C_{W}=300 \mathrm{mg} / \ell$ （カオリ ン士砂濃度 $C_{V}=6 \%$ に相当）および $C_{W}=800 \mathrm{mg} / \ell$ （カオ 直流速成分のカラー・コンターを示寸.

全般的に鉛直流速成分Wは, 粗度の直上流近傍で強い 上昇流，直下流近傍で弱い上昇流，粗度キャビティー中 央部で広い範囲に亘って下降流が共通して発生している. また，上昇流および下降流は，半水深より上層では無視 出来る大きさである. 清水流との比較では, $C_{W}=300$ $m g / \ell$ では上昇流は半減、下降流では6割程度にまで減 少し, 粗度キャビティー境界面における運動量輸送は小 さく, 特に $C_{W}=800 \mathrm{mg} / \ell$ では移流による運動量輸送は 無視出来る程度である.

図一8は, 清水流, PSA溶液濃度 $C_{W}=300 \mathrm{mg} / \ell$ および $C_{W}=800 \mathrm{mg} / \ell$ における主流速の鈆直分布が流下方向に変 化する様子を示す. 縦軸および横軸は, 粗度高さkに よって無次元化された. 流速スケールは, 自由水面近傍 の最大流速U。によって無次元化した. なお, 綎軸は流下 方向に $\mathrm{x} / \mathrm{k}=1.0$ 単位で流下方向にずらして表示している. 

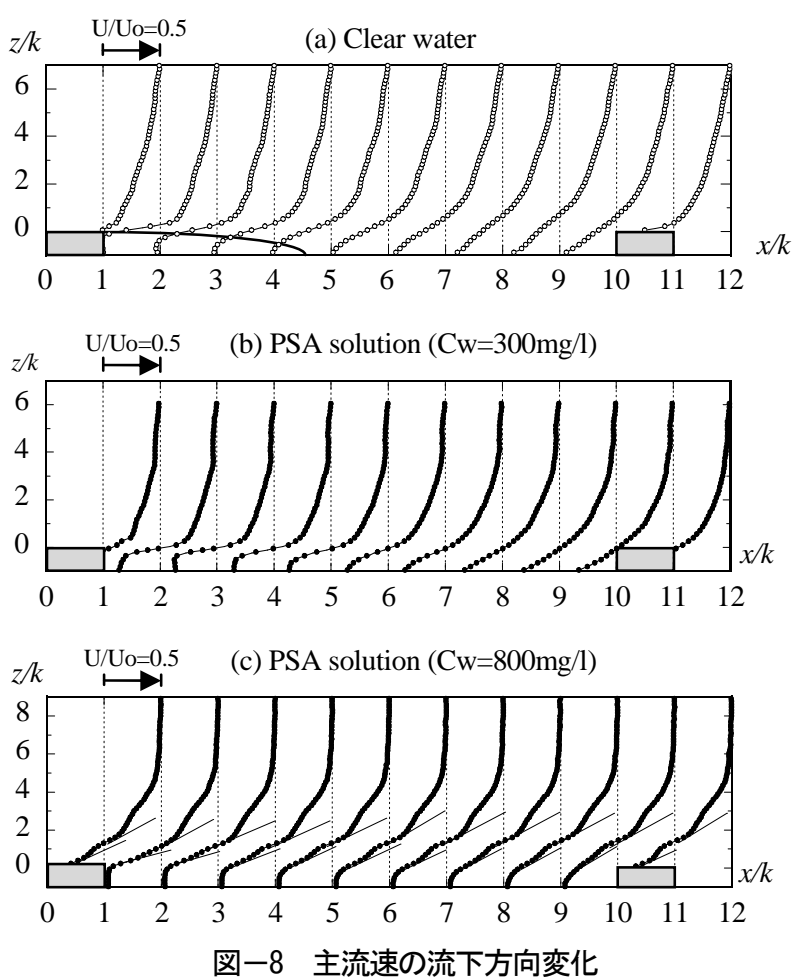

また, PSA溶液 $C_{W}=800 \mathrm{mg} / \ell$ の場合，図中には，主流速 の鉛直変化率が極大值を示す2箇所の位置を実線で示し た.

主流速の鉛直分布は，粗度背後において自由混合層の 特徵を示し，更に下流では，河床面に沿った内部境界層 の発達および順圧力勾配による加速流の影響を受けてい ることが読み取れる. 特にPSA溶液 $C_{W}=800 \mathrm{mg} / \ell$ では, 清水流とは異なりPSA溶液ではせん断速度の大きい領域 が2箇所で明瞭に認められ，高粘性の影響が示唆される. なお，清水流における図中の実線は流れの剥離線を示す。 PSA溶液においては，流れの剥離およびそれに伴う循環 流の形成は顕著ではないことが認められる.

即ち，高粘性のPSA溶液においては，清水流に較べて 循環流の影響が小さいことから，相対的に形状抵抗は小 さく粘性抵抗の大きくなることがわかる.

\section{5. おわりに}

本研究では，二次元角柱粗度を伴う高濃度土砂流の抵 抗特性およびその流動機構を明らかにするために，高濃 度土砂流と類似の粘性特性を有するポリアクリル酸ソー ダ（PSA）溶液を用い, 粒子画像流速計法を適用して, 清水流との比較によってその特性を検討した. 得られた 結果を要約すれば以下の通りである.

1) 粗度高さ $k=5 \mathrm{~mm}(\lambda / k=8)$ および $k=10 \mathrm{~mm}(\lambda / k$ =10）の何れにおいても土砂流は清水流に較べて体積 土砂濃度が $C_{\vee}<8.5 \%$ では抵抗が小さく、逆に $C_{V}>8.5 \%$ では抵抗が大きい

2) 体積土砂濃度 $C_{V}<8.5 \%$ において抵抗は粗度高さ $k$
$=5 \mathrm{~mm}$ では $C_{V}=4-6 \%$ で極小值を示し,$\Delta h / h_{0}\left(C_{V}=0\right)=$ $-0.16, C_{f K} / C_{f W}=0.54, k=10 \mathrm{~mm}$ では $C_{V}=6 \%$ で極小 值を示し $\Delta h / h_{0}\left(C_{V}=0\right)=-0.15, C_{f K} / C_{f W}=0.66$ で有 意な抵抗減となる.

3) 体積土砂濃度 $C_{V}=10 \%$ においては $k=5 \mathrm{~mm}$ で $\Delta h / h_{0}\left(C_{V}=0\right)=0.19, k=10 \mathrm{~mm}$ で $\Delta h / h_{0}\left(C_{V}=0\right)=0.15$, 抵抗係数 $C_{f K} / C_{f W}$ は、 $k=5 \mathrm{~mm}$ で1.68, $k=10 \mathrm{~mm}$ で 1.63であることから抵抗の増加が著しい。

4) PSA 溶液の濃度 $C_{W}=300 \mathrm{mg} / \ell$ （カオリン土砂濃度 $C_{V}=6 \%$ に相当）および $C_{W}=800 \mathrm{mg} / \ell （$ カオリン土砂濃 度 $C_{V}=10 \%$ に相当）において時間平均流の主流速成分 のカラー・コンターから顕著な剥離循環流は形成しな い。このため高粘性のPSA溶液においては，清水流に 較べて相対的に形状抵抗は小さく粘性抵抗の大きくな ることが示唆される.

\section{参考文献}

1) Bradley,J.B. and McCutcheon,S.C : The effects of high sediment concentrantion on transport processes and flow phenomena, proc. Conf.Erosion,Debris prevention,Japan. 1985

2) Z.Y.Wang: Structural features of turbulent flow of clay suspensions over rough boundary. Research Report, Inst.f.Wasserbau and Kulturtechnik, University of Karlsnuhe. 1993

3) 銭寧，高含沙水流連動，清華大学出版社，1989.

4) P.Coussot : Rheology of debris flow - Study of concentrated suspensions. Ph.D. thesis, INPG, Grenoble, 1992

5) 芦田和男・山野邦明・神田昌幸 : 高濃度流れに関寸る研究(1)一粘 性係数と沈降速度一, 京都大学防災研究所年報, No.28,B2,1985,pp367-377

6）江頭進治・芦田和男・田野中新・佐藤隆宏 : 泥流に関する研究, 京都大学防災研究所年報, No.35,B-2, pp79-88, 1992

7) Toms,B.A. : Some Observations on the Flow of Linear Polymer Solutions though Straight Tubes at Large Reynolds Numbers, proc. First Intern. Congr. On Rheology, Vol. II , pp.134-141,North Holland Amsterdam, 1948

8) 宗像瑞恵: 添加剤による抵抗低减流孔に関寸る研究，熊本大学・ 学位論文, pp,47-74,2002

9) Thomas C. Pierson: Hyperconcentrated flow-transional process between water flow and debris flow, pp.159-202, Debris-flow Hazards and Related Phenomena edited by Matthias Jakob and Oldrich Hungr, Springer, 2005

10) 大本照憲・崔 志英・柿原ゆり：高濃度土砂流の抵抗特性につ いて，応用力学論文集Vol.7, pp.979-986,2004

11) 崔 志英・大本照憲・古賀 聖: 非ニュートン流体特性を有す る高濃度土砂流の抵抗特性, 応用力学論文集Vol.9, pp.883892,2006

12）大本照憲、Sukamo Tohirin、Liany Hendratta ：角柱粗度を有す る開水路粗面乱流における抵抗則と運動量輸送, 土木学会論文集 B1(水工学), Vol.68, No.4, I_901-I_906, 2013.2

13) Yang,C.T. and X.Kong : Energy Dissipation Rate and Sediment Transport, Joumal of Hydraulic Reasearch, Vol.29,no.4,pp.457-474, 1991

14) Z.Y.Wang: A study on debris flow surges, Hydraulic Engineering'93, Vol.2, American Society of Civil Engneers, New York,pp. 16161621,1993

15) Z.Y.Wang, , P.Larsen, F. Nestmann, and A. Dittrich:RESISTANCE AND DRAG REDUCTION OF FLOWS OF CLAY SPENSIONSJ. Hydr. Engi.,ASCE,Vol 124, No.1, 1998.

(2013. 9. 30受付) 